\title{
PENGATURAN CAIRAN SECARA MANDIRI PADA KLIEN YANG MENJALANI HEMODIALISIS
}

\author{
Krisna Yetti Malawat*
}

\begin{abstract}
Abstrak
Salah satı stresso- yang dialani oleh $k$ ien End Stage Rend Disease (ESRD) sebagai axibat tidak berfungsinya ginjal adalah masalah kelebihan cairan. Pengaturan pemasukan cairan akin mengu angi penambahan cairan di dalem pembuluh taraj antara dua wakt hemodiklisis (HD). Merujuk pada teori Orem tentang Self Care, diyikini bahwa klien mempunyai kenampuar untuk mengarur pemasukan cairan secara mandir. Be:dasarkan teori inidikembangkan suatu program untuk mengencalikan cairan untuk menolong Hitien HD yang mengalami selebihan cairan di suatu numah sakit umum di Jakarta pada tahum. Dari 24 klien HD yang berhasil inenyelesaikar program ini 2 orang $(8 \%)$ serada pada gratik baik, 15 orang $(63 \%)$ berada pada grafik rata-rata, dan 7 orang $(29 \%)$ berada pada grafik bahaya
\end{abstract}

Kata kunci: ESRD, kelebihan cairan, mandiri

\section{Abstract}

Fluid overload is one of the stresscrs experienced by End Stage Rend Diseast clients. The management of Juid intake will minimize the amount of fluid in blood wessal inter-Aialysix time. Refor to Oren theory of seif-care, it is balieved that hamodialysis (HD) clients have the ability to reguate their fiwid intake. Buse on this theory it was developed a program for aelping HD dients to redice their fluid overload in a jublis hospital in Jakurta Twenty-four HD clients have completsd the program succossfully, who were $8 \%$ in good graphic, $63 \%$ in avercge graphic, and $200 \%$ in dangerous graphic

Key words: ERSD, fluid overload, self-care

Penelitian dibiayai sleh Drayfus Foundation melalsi PUSKA-U!

\section{PENDAHULUAN}

Ginjal adalah organ yang berfungsi untuk menyaring serta nengeluarkan sisa-sisametabolisme vang tidak diperlukan lagi oleh tubun (Richard, 1986, hal 20; Lindqvist \& Sjoden, 1998), Jika fungsi ginjal menurur sampai ke tahap Fnd Stage Renai Disease (ESRD) yang ditandai menurunnya fungsiginjal sampai 10 lebih rendah, maka cairan-elektrolit dan sisa-sisa metabolisme tidak dapat dikeluarkan dari tubuh.

Hemodialis s sebagai salah satu alternatif terapi jengganti pada ESRD telah dibuktikan sangat efektif nengeluarkan cairan-elektrolit dan sisa-sia metabolisme ubuh. Sesuai dengan cara kerjanya, hemodialisis hanya dilakukan dalan 2-3 kali perminggu, dan 45 jam per kali dialisis, sehingga cairan-elektrolit dan sisa metabolisme yang selalu terbentuk dari waktıke waktu akan tetap beraca delam peredaran darah di uar walktu dialisis. Keberadaan cairan-elektrolit dan sisa-sisa metabolisme ini menimbulkan berbagai masalah yang dikenal dengan stressor. Stressor ini cialani klien secara menetap atau berkepanjangan, muncul setiap saat sampai klier meninggal.

Beberapa perelitian yang dilakukan untuk menget:hui stressor vang dialami oleh klien hemodialisis (HD) melaporkan bahwa masalah cairan merupakan 
salah satu masalah utama (Baldree, 1982; Gurklis \& Menke, 1988: Lok, 1996: Germino, 1998; dan Lindqvist \& Sjoden, 1998). Meskipun belum ada laporan tentang penelitian yang sama di Indonesia, berdasarkan observasi diasumsikan bahwa masalah cairan juga merupakan salah satu stressor urama yang dialami klien HD. Berdasarkan asumsi ini dilakukan suatu program pembatasan cairan di suatu rumah sakit umum pusat di Jakarta dari bulan Maret 1999 sampai dengan bulan September 1999.

Program pembatasan cairan ini diikuti oleh 31 klien HD, dan sampai akhir program 24 orang berhasil menyelesaikannya. Tujuh belas orang berada pada grafik baik dan rate-rata.

\section{LANDASAN TEORITIS}

Permasalahan cairan dari tingkatyang ringan sampai berat dialami oleh klien hemodial sis. Tecri "Orem" tentang "Self Care" dengan tujuan memandirikan klien untuk mengatur pemasukan cairan diaplikasikan pada klien ESRD.

\section{Kelebihan Cairan, Suatu Stressor bagi klien HD}

End Stage Renal disease (ESRD) meripakan penyakit ginjal kronik, dimana fungsi ginjal mengalami gangguan. Fungsi ginjal dalam keadaannormal adalah untuk mempertahankan homeostasis lingkungan internal dengan memproduksi urin dan zat terlarutnya, elektrolit, asam-basa, dan memproduksi hormon (Richard, 1986, hal.20; Lindqvist \& Sjoden, 1998). Bila faal menurun yang ditandai dengan menurunnya fungsi ginjal sampai dengan $10 \%$ atau lebih rendah, maka kemampuan ginjal untuk mempertahankan homeostasis ini terganggu. Gangguan yang terjadi adalah ticak diproduksi urin dan zat terlarutnya, serta tidak berfungsinya ginjal untuk membentuk hormon.

Ada tiga jenis terapi pengganti yang tersedia untuk mempertahankan fungsi tutuh padatahap ESRD. Salah satunya adalah hemodialisis (HD), dan dua lainnya adulah Peritoneal Dialisis (PD), dan transplantasi ginjal.
Terapi pengganti HD dan PD ini tidak hersifat kuratif, karena tujuannya adalah menghilangkan gejala dan memperpanjang umur hidup klien (Fallon, Gould, \& Wainwright, 1997).

Klien yang menjalani program hemodialisis mengalami berbagai masalah, karena ESRD sebagai penyakit kronik bersifat irreversible, masalah yang timbul akibat tidak berfungsinya ginjal selalu muncul setiap waktu, dan tidak pemah berakhir sampai akhir hayat klien(Germino, 1998). Masalahini merupakan stressor fisiologika, yang padaakhirnya juga menjadi stressor psikologikal. Stressor fisiologikal maupun psikologikal perlu ditanggulangi secara akurat (Baldree. 1982; Gurkis \& Menke, 1988; Lok, 1996; Germino, 1998; Linqvist \& Sjoden, 1998). Dari laporan penelitian, salah satu stressor yang merupakan masalah utama yang dihadapi klien HD adalah kenaikan berat badan antara dua waktu dialisis karena penambahan caizan di dalam tubuh menjadi nol mililiter sulit atauticak mungkin didapat.

Penambahan berat badan ini disebabkan pemasukancairan melebihi kebutuhan tubuh Kelebihan cairan ini akan berakibat pada organ panu, jantung, can sistem saraf, dimana organ ini akan bekerja lebih berat. (Lawrence, 1987). Sebagai akibatnya, klien HD akan mengalami gejala-gejala kelebihan cairan yaitu mengalami gangguan pada saat berrafas, tekanan darah meningkat, tidak bisa berbaring, dan sakit kepala (Lancaster, 1991). Pada kelebihan cairan yang ekstrim, dapat berakibat fatal yaitu mengakibatkan kematian.

Pemahamen dan kemampuan kien untuk mengatur pemasukan cairan yang mendekati kebutuhan cairan tubuh diperlukan untuk menghindari akibat kelehihan cairan ini.

Pemasukan cairan dalam 24 jam yang diarjurkan untuk klien HD adalah:

$500 \mathrm{cc}$ (IWL) + produksi urin/ 24 jam. 
Sebagai sontoh sesecrang yang mengeluarkan urin 300 cc/24 jam, maka zairan yang boleh dikonsumsi adalah: $500 \mathrm{cc}+301 \mathrm{cc}=800 \mathrm{cc} / 24 \mathrm{jam}$.

\section{Kriteria kenaikan berat badan}

Merujuk pada Kozier et.al. (1991), pencliti mengelompokkan kenaikan herat badan kliea HD dewasa antara dua waktu dialisis menjadi 3 bagia., yaitu 1 . Ringan, penambahan mencespai $2 \%$ dari berat badan kering; 2 . Sedang: penambahan mancapai $5 \%$ dari berat badan ke:ing, dan 3. Be:at: penambahăn meneapai $8 \%$ dari berat badan kering.

Berdasarkan kriteria ini Yetti i 1999) membuat 3uatu format yang diberi nama "Pencatatan Kenaikan Berat Badan Setiap Hari" "lihat gambar 1). Format ini digunakan untuk menganalisis kenaikan berat badan dengan membuct suatu rentang, yaitu kenaikan berat adan sampai dengan $4 \%$ disebut baik, $4 \%$ sampai $5 \%$ disebut rata-raia, can $6 \%$ sampai $10 \%$ disebut bahaya.

\section{Gambar 1.}

Pencatatan Kenaikan Berat Badan Klien HD Setiap Hari

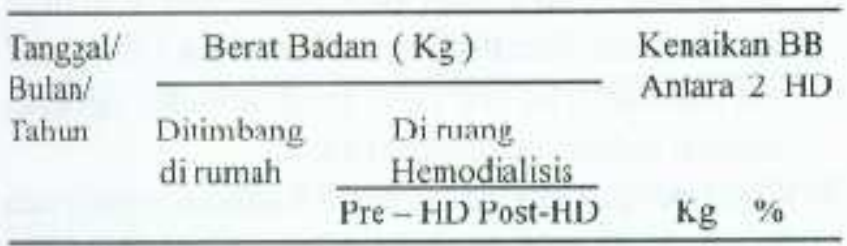

1

2

3

‥

dst

\section{Teori Self Care}

Orem pada tahun 1959 menyampaikan pandangannya yang kemudian menjadi suatu teori yang dikenal dengan Teori Self Care, bahwa manusia mempunyai kemampuan untuk merawat diri sendiri. Apabila terjadi SelfCare Deficit maka klien tidak dapat memenuhi kebutuhanuntuk merawat diri sendiri. Teori ini sangat sesuai untuk klien kronik seperti klien HD. Aplikasi teori ini adalah memberdayakan klien untuk bertanggung jawab dalam mempertahankan kenaikan berat badan antara dua waksu dialisis seminimal mungkin. Caranya adalah klien HD menimbang berat badan setiap pagi, menganalisis kenaikan berat bacan lalu, mencatat kenaikan berat badan ini pada buku catatan "Rentang Kenaikan Berat Badan Antara Dua Waktu Dialisis" (gambar 2.) Hasil analisis in menpakan input bagi klien berapa banyak cairan yang boleh masuk pada hari itu.

Gambar 2.

Rentang Kexaikan Berat Baden Antara Dua Waxtu Dialisis

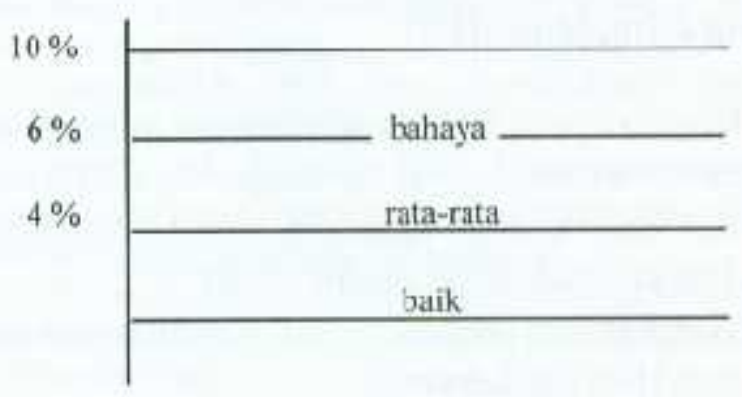

\section{LANGKAH-LANGKAH PROGRAM}

Program ini berlangsung selama enam bulan. Langkah-langkah pelaksenaan program ini dibagi menjadi empat tahapan: tahap Persiapan, Imolementasi, Evaluasi, can tahap terakhir adalah Termirasi.

\section{Tahap 1. Persiapan}

Tahap persapan ini terdiri dari 7 kegiatan yaitu:

1. Penyusunan bahan untuk pendidikan kesehatan, yang melputi brosur, buku catatan $\mathrm{HD}$, dan makalah tentang masalah-masalah yang dihadapi klien HD dan upaya menanggclanginya. 
2. Mengajukan permohonan izin peda penanggung jawab unit HD serta menginformasikan rencana kegiatan kepada anggota tim yang terdiri dari perawat ruangan $\mathrm{HD}$ dan ahligizi

3. Melatih tenaga kesehatan untuk bertindak sebagai fasilitator penyelenggaraan program

4. Menginfo:masikan kepada klien HD dan keluarga tentang rencana pelaksanaan srogram

5. Menetapkan tanggal pertemuan untuk menjelaskan kepada klien HD dan keluarga

6. Menentukan klien IID yang akan diikut-sertakan pada prog-am pembatasan cairan ini

7. Mengundang klien HD dan keluarga

Setelah langkah-langkah ini selesai dilaksanasan, maka langkah berikutnya adalah memasuki tahap implementasi

\section{Tahap 2. Implementasi}

Kegiatan pada tahap implementasi merupakan pertemuar antara anggota tim dengan klien HD dan keluarga yang berlangsung selama empat jam. Secara rinci kegiatan pada tahap dua ini adalah:

1. Mengenalkan prcgran untuk membatasi cairan pada klien dar keluarga

2. Membahas tentang maselah yang dihadapi dan upaya menanggulanginya, serta memberikan penjelasan tentang kenaikan berat badan antara dua waktu dialisis. Pembahasan ini disarikan dalam suatu makalah

3. Menjelaskan isi brosu; penimbangan berat badan dan peng.sian buku catatan HD serta makna kenaikan berat badan

4. Memizjamkan timbangan kepada klien IID dan keluarga sebagai suatu alat untuk memantau kenaikan berat badan

5. Melakukan diskusi. Hasil diskusi diantaranya adalah keinginan klien $\mathrm{HD}$ untuk bertemu secara be kala dengan tim keehatan, dan keinginan untuk berekreasi bersama petugas kesehatan
Pertemuan ini memberi suatu kepuasan pada klien dimana mereka dapat mengklarifikasi perasaanperasaannya selama ni sertamemberikan saran untuk perbaikan pelayenan kesehatan.

\section{Tahap 3. Evaluasi}

Keg atan pada tahar evaluasi iri ditujukan untuk memantau kenaikan berat badan klien $\mathrm{HD}$ antara dua waktu dialisis. Pemantauan ini dilaksanakan:

1. setiapminggu untuk dua minggu pertama

2. setiapdua minggu selama empat minggu berikutnya

3. seciap bulan sampai dengan bulan terakhir

Tahap in merupakan suatu media bagi arggota tim kesehatan dan klien HD beserta keluarganya untuk membahas masalah-rnasalah yang belum terjawab paca tahap dua.

\section{Tahap 4. Terminasi}

Sesuai dengan namanya, tahap in merupakan suatu kegiatan yang bertujuan untuk mengakhiri program. Kegiatan pada tàap ini edalah:

1. Membahas hasil yang telah dicapai klien HD yang berlangsung selama enam bulan. Grafik rata-rata kenakar berat baden antara dua waktu dialisis dibalas dan ciserahkan nada klien HD. Dari grafik ini diketahui upaya yang telah mereka lakukan selama meng.kuti program in.

2. Klien dengan keraikan berat badan berada pada rentang rata-rata menyampaikan kiat yang mereka lakukan selama mengikuti program ini,

3. Membahas hambatan bagi klien yang berada pada grafik bahaya

4. Membentuk paguyuban klien HD. Paguyuban ini dilarapkan menjadi sarana untuk mambahas dan mencari jalan keluar permasalahan yang dialamiklien HD

Meskipun program pembatasan cairan ini berakhir, bukan berartikegiatan yang juga berakhir. Diharapkan upaya-upaya yarg telah dirintis dapat d.pertahankan dan ditcrusken kepaca klien HD lain. 


\section{HASIL DAN PEMBAHASAN}

Jumlahklien HD yang nengikuti kegiatan di awal program adalah 31 orang, sedangkanjumlah slien yang dapat menyelesaikan program ada.ah 24 orang atau yang tidak dapat menyelesaikan program adalah tujuh orang. Tidak semua klien HD dapat menyelesaikan program ini dikarenakanempat orang meninggal duna, satupindah ke unit dialisis lain, dan dua tidak mengikuti program hemodialisis secara reguler. Mengingat program in bertujuan untuk mengubch perilaku, maka peribahan yang terjadi sangat signifikan, yaitu 17 dari 24 orang $(70 \%)$ berada pada grafik baik dar rata-rata. Keterhasilan ke-2 $<$ klien HD mengendalikan berat badan antara dua waktu dialisis dapat dilihat pada gambar iga.

\section{Gambar 3.}

Hasil Pengendalian Kexaikan Berat Badan Klien HD (Sclama Enem Bulani

\begin{tabular}{l|ll}
$10 \%$ & & \\
\cline { 2 - 3 } $6 \%$ & 7 orang & bahaya \\
\cline { 2 - 3 } $4 \%$ & 15 orang & rata - rata \\
\cline { 2 - 3 } & 2 mang & haik
\end{tabular}

Seleksi klien HD untuk mengikuti program ini hanya didasarkan pada kenaikan berat badan melebihi $5 \%$ dari berat badan kering selama 6 bulan berturutturut sebelum mengikuti program ini. Perlu dipertimbangkan kriteria lain untuk seleksi klien, sehingga program pembatasan cairan ini dapat ditentukan tingkat validitasnya. Tidak tertutup kemungkinan ada faktor lain yang turut menunjang keherhasilan program ini. Oleh karena itukegiatan yang sama perlu diujicobakan di unit HD lain untuk mergetahui validitas progran ini.

\section{KFSIMPII,AN}

Masalah kelebihan cairan mezupakan salah satu stressar yang dialami oleh klien HT) Berdasarkan tenri Orem diyakini bahwa klien HD dapat merawat dirinya sendiri sehingga dapat mengatur jemasukan cairan merupakan dasar pelaksanaan program pembatasan cairan. Perlu dikembangkan kriteria pemilihen klien dan dilakukan uji coba program pembatasan cairan di unit $\mathrm{HD}$ lain, untuk mengetahui tingkat validitasnya $(\mathrm{HH}$. RS).

\footnotetext{
* K-isna Yetti Malawat, SKp., M.App.Sc.: Staf Penga ar Bagian Dasar Keperawatan das Keperawatan Dasar FIK-UI
}

\section{KEPUSTAKAAN}

Fallon, M., Gould, D., \& Wainwright, S P. (1997), Stress and quality of life in the renal traniplant patient: A preliminary invostigation. Journa of Advance Nursing, $25,562-570$

Germino, B.B. (1998). When a chronic illness become terminal. ANNA Journal, 25(6), 579-582.

Gurklis, J.A, \& Menke, E.M. (1988). Identification of stressar: anc' use of coping methods in chronic hemodialysis patients, Nursing Research, 37(4), 236-239.

Kozier, B., Erb, C. \& Oliveri, R. (1995). Fundamentals of nursing: Concepts, process and pracilce. Redwoot City: Addison-Wesley

Larcaster,L.E. (1991)(Ed.1. Core curriculum for nephrology marsing. ( $2^{\text {wed }} e$ ). New Jersey : Anthony J, Jannati. Inc

Lindqvist, R \& Sjoden, P. (1958). Coping strategies and quality cf life among patients on continuous ambulatory peritoneal dialysis (CAPD), Journal of Advanced Nursing, 27. $312-319$

Lok, P. (1995). Siressor, coping mechanism and quality of life anong dialysis patients in Australia Journal of A.dvanced Nursing $23,873-881$

Richard, C. J.(1986). Comprenensive nephrology nursing. Bos.on: Little Brown Comp. 